\title{
BEBERAPA FAKTOR YANG BERHUBUNGAN \\ DENGAN KEPUASAN PELAYANAN ANC DI BIDAN DESA \\ KUNGKAI KECAMATAN BANGKO WILAYAH KERJA \\ PUSKESMAS BANGKO
}

\author{
Dewi Nopiska Lilis \\ Dewi2@gmail.com \\ Program studi kebidanan Poltekes Jambi \\ SOME FACTORS RELATED TO ANC SERVICE \\ SATISFACTION IN MID WIFE DESA KUNGKAI \\ KECAMATAN BANGKO WORKING AREA OF PUSKESMAS \\ BANGKO
}

\begin{abstract}
Abstrak
Berdasarkan survei awal yang telah dilakukan di Bidan Desa Kungkai Tahun 2017 terdapat rendahnya cakupan pelayanan antenatal care. Maka tujuan penelitian ini untuk mengetahui beberapa faktor yang berhubungan dengan kepuasan pelayanan ANC di Bidan Desa Kungkai Kecamatan Bangko wilayah kerja Puskemas Bangko tahun 2017. Penelitian ini menggunakan metode analitik menggunakan rancangan cross sectional. Populasi dan sampel penelitian ini adalah seluruh ibu hamil yang memeriksakan kehamilan di Bidan Desa Kungkai Kecamatan Bangko Tahun 2017 yang berjumlah 64 orang.Hasil penelitian didapatkan dari 64 orang ibu hamil tersebut dilihat dari IKM setelah dikonversi yaitu 56,6 dengan mutu pelayanan $\mathrm{C}$ kinerja unit pelayanan kurang puas. Teknik pengumpulan data dengan menggunakan kuesioner, pengolahan data dengan manual, analisis data bivariat dengan Chi Square Test.

Hasil analisis menunjukkan ada hubungan antara umur, pendidikan dan status pekerjaan dengan kepuasan terhadap pelayanan ANC di Bidan Desa Kungkai Tahun 2017. Penelitian ini diharapkan dapat dimanfaatkan oleh bidan desa supaya dapat memberikan pelayanan yang bermutu untuk meningkatkan derajat kesehatan masyarakat di Desa Kungkai Kabupaten Merangin.
\end{abstract}

Kata kunci : Kepuasan dan ANC

\section{Abstrac}

Collecting antenatal care coverage. Based on the initial survey conducted in Kungkai Village Midwife in 2017 there is a low coverage of antenatal care services. So the purpose of this study is to find out several factors related to satisfaction of ANC services in the Kungkai Village Midwife, Bangko Subdistrict, Bangko Community Health Center working area in 2017. This study uses an analytical method using a cross sectional design. The population and sample of this study were all pregnant women who examined pregnancy in the Kungkai Village Midwife, Bangko Year 2017 District, which amounted to 64 people. The results of this study were obtained from 64 pregnant women from the IKM after conversion, 56.6 with service quality $\mathrm{C}$ service unit performance less satisfied. Data collection techniques using questionnaires, data processing with manual, bivariate data analysis with Chi Square Test.

The results of the analysis show that there is a relationship between age, education and employment status with satisfaction with ANC services in Kungkai Village Midwife in 2017. This research is expected to be used by village midwives in order to provide quality services to improve community health in the Kungkai Village of Merangin Regency.

Key points: ANC satisfaction 
PENDAHULUAN

Angka kematian ibu (AKI) di Indonesia sampai saat ini masih tinggi, dan ini merupakan suatu masalah kesehatan yang sampai saat ini belum dapat diatasi secara tuntas. AKI merupakan salah satu indikator untuk melihat derajat kesehatan seorang perempuan. Menurut Survei Demografi dan Kesehatan Indonesia $(\mathrm{SDKI})^{1}$ pada 2012, AKI di Indonesia tercatat sebesar 359/100.000 kelahiran hidup. Penyebab kematian maternal di Indonesia menurut Depkes RI 2010 adalah perdarahan $42 \%$, eklampsia $13 \%$, komplikasi abortus $11 \%$, infeksi $10 \%$ dan persalinan lama $9 \%$.

Berdasarkan data Human Development Report 2012, AKB di Indonesia mencapai 32 per 1.000 kelahiran.Berdasarkan data ini Angka Kematian Bayi (AKB) di Indonesia lebih banyak bila dibandingkan dengan Angka Kematian Ibu. Tingginya AKB diantaranya disebabkan masih banyaknya persalinan yang dilakukan dirumah dan usia ibu yang terlalu muda ataupun terlalu tua.
Safe Motherhood di Indonesiaditerjemahkan sebagai upaya kesejahteraan/keselamatan ibu. Istilah "Kesejahteraan Ibu" menunjukkan ruang lingkup yang lebih luas, meliputi hal-hal diluar kesehatan, sedangkan "Keselamatan Ibu" mempunyai konotasi yang terkait langsung dengan aspek kesehatan. Tujuan safe motherhood adalah untuk menurunkan angka kesakitan dan kematian ibu hamil, nifas, disamping menurunkan angka kesakitan dan kematian bayi baru lahir. Upaya ini terutama ditunjukkan kepada negara yang sedang berkembangan, karena 99\% kematian ibu di dunia terjadi di negara-negara tersebut ${ }^{2}$.

$$
\text { Pada tahun } 2012
$$

Kementerian Kesehatan RI meluncurkan program EMAS (Expanding and Neonatal Survival), bekerjasama dengan USAID dengan kurun waktu 2012-2016 yang diluncurkan 26 januari 2012 sebagai salah satu bentuk kerjasama pemerintah Indonesia dengan USAID dalam rangka percepatan penurunan AKI dan AKB. Upaya yang dilaksanakan adalah dengan 
peningkatan kualitas pelayanan emergency obstetri dan neonatal dengan cara memastikan intervensi medis prioritas yang mempunyai dampak besar pada penurunan kematian dan tata kelola klinis diterapkan di RS dan Puskesmas. Upaya lain dalam program EMAS ini dengan memperkuat sistem rujukan yang efisien dan efektif mulai dari fasilitas pelayanan kesehatan dasar di puskesmas sampai ke RS rujukan tingkat kabupaten. Program ini juga akan mengembangkan mekanisme umpan balik dari masyarakat kepemerintah daerah menggunakan teknologi informasi seperti media sosial dan memperkuat forum masyarakat agar dapat menuntut pelayanan yang lebih efektif dan efisien melalui maklumat pelayanan ${ }^{3}$.

Upaya pemerintah yang lain untuk menekan AKI dan AKB yaitu dengan adanya program Badan Penyelenggara Jaminan Sosial (BPJS), lewat program ini, perempuan melahirkan dibebaskan dari biaya. Kemudian adanya program Antenatal Care (ANC) yaitu kunjungan ibu hamil ke bidan atau ke dokter sedini mungkin semenjak ia merasa dirinya hamil untuk mendapatkan pelayanan/asuhan antenatal. ${ }^{4}$ Dalam rencana strategi Kementerian Kesehatan tahun 2014 telah ditetapkan target untuk kunjungan Antenatal Care dan penanganan komplikasi yaitu target K1 $100 \%$ dan K4 95\%, pertolongan persalinan oleh tenaga kesehatan $90,88 \% .^{5}$

Cakupan pelayanan Antenatal

Care ditingkat nasional 2014 menunjukkan cakupan K1 sebesar 92,25\% dan K4 sebesar $86,85 \% .{ }^{5}$ Cakupan K4 sebesar $86,85 \%$ tersebut menunjukkan cakupan yang tidak mampu mencapai target.Kondisi tersebut merupakan masalah pelayanan kesehatan ibu hamil yang dapat dilihat sebagai masalah mutu pelayanan ANC, karena cakupan ANC sesungguhnya adalah kinerja petugas pemberi pelayanan dan kepuasan masyarakat terhadap pelayanan yang diberikan. Oleh karena itu capaian cakupan ANC merupakan gambaran dari mutu pelayanan yang diberikan oleh bidan atau merupakan gambaran dari kepuasan masyarakat terhadap 
pelayanan yang diberikan.Suatu

pelayanan kesehatan dinyatakan

bermutu apabila memberikan

kepuasan kepada pasien. Survey

kepuasan pasien menjadi penting dan

perlu dilakukan bersamaan dengan

pengukuran dimensi mutu layanan

kesehatan yang lain. ${ }^{6}$

Data cakupan ANC wilayah kerja Puskesmas Bangko tahun 2015 menunjukkan bahwa, cakupan K1 89,9\% dan cakupan K4 81,1\%. Dari 10 jumlah Desa di Unit Puskesmas Bangko untuk Desa Kungkai pada tahun 2015 K1 71,7\% dan K4 54,4\%, menunjukkan jauh dibawah target nasional sebesar 95\% terutama untuk cakupan $\mathrm{K}^{7}{ }^{7}$

Fenomena rendahnya cakupan K4 tersebut dijadikan sebagai dasar untuk menetapkan ranah penelitian dengan beberapa kemungkinan seperti penelitian tentang kinerja bidan desa, penelitian terhadap karakteristik individu dan penelitian tentang mutu pelayanan ANC.

\section{TUJUAN PENELITIAN}

Secara umum diketahuinya beberapa faktor yang berhubungan dengan kepuasan pelayanan
Antenatal Care di Bidan Desa Kungkai Kecamatan Bangko Wilayah Kerja Puskesmas Bangko. Secara khusus diketahuinya tingkat kepuasan ibu hamil tentang pelayanan ANC; hubungan antara umur ibu hamil dengan kepuasan ibu hamil tentang pelayanan antenatal care; hubungan antara pendidikan ibu hamil dengan kepuasan ibu hamil tentang pelayanan ante natal; hubungan antara pekerjaan ibu hamil dengan kepuasan ibu hamil tentang pelayanan antenatal oleh Bidan Desa Kungkai Kecamatan Bangko Wilayah Kerja Puskesmas Bangko Tahun 2017.

\section{METODE PENELITIAN}

Penelitian ini merupakan penelitian survey analitik menggunakan rancangan potong lintang (cross sectional), dilakukan terhadap Bidan Desa Kungkai Kecamatan Bangko Wilayah Kerja Puskesmas Bangko dengan rentang waktu pada bulan Mei-Juni Tahun 2016. Populasi pada penelitian ini adalah seluruh ibu hamil yang pernah melakukan pemeriksaan kehamilan di Bidan Desa Kungkai Kecamatan Bangko dari bulan Januari tahun 
2016 s/d Januari tahun 2017 yang berjumlah 64 orang. Sampel yang digunakan adalah total populasi.

Variabel terikat dalam penelitian ini adalah kepuasan ANC dan varibel bebasnya adalah pendidikan, umur dan pekerjaan. Analisa data dalam penelitian ini dilakukan dengan 2 tahap yaitu analisis univariat dan analisis bivariat.Uji statistik dengan menggunakan ujiChi Square.

\section{HASIL PENELITIAN}

\section{a. Analisa Univariat}

\section{Tingkat Kepuasan Pelayanan Antenatal}

Tingkat kepuasan ibu hamil terhadap pelayanan antenatal di Bidan Desa Kungkai Kecamatan Bangko tahun 2016 yang di ukur dengan IKM adalah sebesar 56,6 dengan mutu pelayanan $\mathrm{C}$ termasuk kategori kurang puas, sebagaimana tertulis pada Tabel 1 berikut :

Tabel 1. Tingkat Kepuasan Ibu Hamil Tentang Pelayanan ANC Oleh Bidan Desa Kungkai Tahun 2017

\begin{tabular}{crc} 
NO & \multicolumn{1}{c}{ Indikator } & Kesimpulan \\
\hline 1. & IKM setelah di konversi & 56,6 \\
2. & Mutupelayanan & $\mathrm{C}$ \\
3. & Kinerja unit pelayanan & Kurangpuas \\
\hline
\end{tabular}

\section{b. Analisa Bivariat}

Analisa bivariat dimaksudkan untuk menganalisis hubungan antara umur, pendidikan dan status pekerjaan dengan kepuasan terhadap pelayanan ANC. Berdasarkan hasil ukur kepuasan pada definisi operational kepuasan terdiri dari 4 kategori yakni sangat puas, puas, kurang puas dan tidak puas. Dari 4 kategori tersebut pada pengolahan data hanya ditemukan 3 kategori yakni sangat puas, puas dan kurang puas.

Pada analisis bivariat menggunakan 3 kategori kepuasan tersebut, ditemukan adanya 2 sel dengan $\mathrm{E} \leq 5$ berarti $\geq 20 \%$ sel dengan $\mathrm{E} \leq 5$. Oleh karena itu tidak terpenuhi syarat untuk melakukan analisis bivariat.Pada kondisi demikian dilakukan penggabungan kategori kepuasan, dari 3 kategori tersebut menjadi 2 kategori yakni menggabungkan kategori sangat puas menjadi puas. 


\section{Hubungan Umur dengan Kepuasan}

Hubungan umur ibu hamil dengan kepuasan ibu hamil terhadap pelayanan ANC di Bidan Desa Kungkai Kecamatan Bangko Tahun 2017.

Tabel 2. Hubungan Umur Ibu Hamil Dengan Kepuasan PelayananANC Di Bidan Desa Kungkai Kecamatan BangkoTahun 2017

\begin{tabular}{lccccccc}
\hline & \multicolumn{3}{c}{ Kepuasan } & \multicolumn{5}{c}{ Jumlah } & \multirow{2}{*}{ Umur } \\
\cline { 2 - 5 } & \multicolumn{2}{c}{ Kurangpuas } & \multicolumn{2}{c}{ Puas } & \multirow{2}{*}{$\mathrm{n}$} & $\%$ & \multirow{2}{*}{$\chi^{2}$} \\
\cline { 2 - 6 } Muda & 18 & 64,3 & 13 & 36,1 & 31 & 48,4 & \\
Tua & 10 & 35,7 & 23 & 63,9 & 33 & 51,6 & 5,05 \\
Jumlah & 28 & 100 & 36 & 100 & 64 & 100 & \\
\hline
\end{tabular}

Berdasarkan Tabel 2 diatas menunjukkan bahwa persentase terbanyak yang merasa kurang puas berdasarkan kategori umur adalah pada responden yang muda sebanyak 18 orang $(64,3 \%)$ dan responden dikategorikan tua yang merasa kurang puas sebanyak 10 orang $(35,7 \%)$.

Dari hasil uji statistik di ketahui $\chi^{2}$ hitung sebesar 5,05 yang berarti $\mathrm{H}_{0}$ di tolak dan disimpulkan ada hubungan antara umur dengan kepuasan pelayanan ANC.

\section{Hubungan Antara Pendidikan Dengan Kepuasan}

Hubungan pendidikan ibu hamil dengan kepuasan ibu hamil terhadap pelayanan ANC di Bidan Desa Kungkai Kecamatan Bangko Tahun 2017.

Tabel 3. Hubungan Pendidikan Ibu Hamil Dengan Kepuasan Pelayanan ANC Di Bidan Desa Kungkai Kecamatan Bangko

\begin{tabular}{|c|c|c|c|c|c|c|c|}
\hline \multirow{3}{*}{ Pendidikan } & \multicolumn{3}{|c|}{ Kepuasan } & \multicolumn{3}{|c|}{ Jumlah } & \multirow{3}{*}{$\chi^{2}$} \\
\hline & \multicolumn{2}{|c|}{$\begin{array}{c}\text { Kurang } \\
\text { puas }\end{array}$} & \multicolumn{2}{|c|}{ puas } & \multirow[t]{2}{*}{$\mathrm{n}$} & \multirow[t]{2}{*}{$\%$} & \\
\hline & $\mathrm{n}$ & $\%$ & $\mathrm{n}$ & $\%$ & & & \\
\hline Tinggi & 18 & 54,3 & 12 & 34 & 30 & 46,9 & \\
\hline Rendah & 10 & 35,7 & 24 & 66 & 34 & 53,1 & 5,7 \\
\hline Jumlah & 28 & 100 & 36 & 100 & 64 & 100 & \\
\hline
\end{tabular}


Berdasarkan Tabel 3 diatas menunjukkan bahwa persentase terbanyak yang merasa kurang puas berdasarkan kategori pendidikan adalah pada responden yang berpendidikan tinggi yaitu sebanyak 18 orang (64,3\%), sedangkan responden dengan kategori pendidikan rendah yaitu sebanyak 10 orang $(35,7 \%)$.

Dari hasil uji statistik diketahui $\chi^{2}$ hitung sebesar 5,7 yang berarti $\mathrm{H}_{0}$ ditolak dan disimpulkan ada hubungan pendidikan dengan kepuasan pelayanan ANC.

\section{Hubungan Status Pekerjaan Dengan Kepuasan}

Hubungan Status Pekerjaan Ibu Hamil Dengan Kepuasan Ibu Hamil Terhadap Pelayanan ANC Di Bidan Desa Kungkai Kecamatan Bangko Tahun 2017

Tabel 4. Hubungan Status Pekerjaan Ibu Hamil Dengan Kepuasan Pelayanan ANC Di Bidan Desa Kungkai Kecamatan Bangko

\begin{tabular}{|c|c|c|c|c|c|c|c|}
\hline \multirow{3}{*}{ Pekerjaan } & \multicolumn{4}{|c|}{ Kepuasan } & \multicolumn{2}{|c|}{ Jumlah } & \multirow{3}{*}{$\chi^{2}$} \\
\hline & \multicolumn{2}{|c|}{ Kurangpuas } & \multicolumn{2}{|c|}{ Puas } & \multirow{2}{*}{$\mathrm{n}$} & \multirow{2}{*}{$\%$} & \\
\hline & $\mathrm{n}$ & $\%$ & $\mathrm{n}$ & $\%$ & & & \\
\hline Bekerja & 17 & 60,7 & 11 & 30,6 & 28 & 43,7 & 5,7 \\
\hline Tidakbekerja & 11 & 39,3 & 25 & 69,4 & 36 & 56,3 & \\
\hline Jumlah & 28 & 100 & 36 & 100 & 64 & 100 & \\
\hline
\end{tabular}

Berdasarkan Tabel 4 diatas menunjukkan bahwa persentase terbanyak yang merasa kurang puas berdasarkan kategori pekerjaan adalah pada responden yang bekerja sebanyak 17 orang $(60,7 \%)$, sedangkan pada responden yang merasa kurang puas dengan kategori tidak bekerja sebanyak 11 orang $(39,3 \%)$.

Dari hasil uji statistik diketahui $\chi^{2}$ hitung sebesar 5,7 yang berarti $\mathrm{H}_{0}$ ditolak dan disimpulkan ada hubungan antara status pekerjaan dengan kepuasan pelayanan ANC. 


\section{PEMBAHASAN}

\section{Tingkat Kepuasan Ibu Hamil Terhadap Pelayanan ANC}

Pada penelitian ini ditemukan tingkat kepuasan ibu hamil terhadap pelayanan ANC di Bidan Desa Kungkai berada pada kategori kurang puas dengan IKM sebesar 56,6.Ibu hamil yang kurang puas terhadap pelayanan ANC tersebut berhubungan dengan persepsi ibu kurang puas. Dalam hal itu kurang puas menunjuk pada mutu pelayanan ANC yang masih kurang. Artinya ada hubungan yang sangat berkaitan antara mutu pelayanan dengan kepuasan pasien, semakin baik mutu pelayanan maka semakin tinggi kepuasan pasien. Sebaliknya semakin jelek mutu pelayanan kesehatan, semakin rendah pula kepuasan terhadap pasien.

Secara teori, kepuasan pasien dalam penilaian mutu dihubungkan dengan ketetapan pasien terhadap mutu atau kebagusan pelayanan khususnya pelayanan $\mathrm{ANC}^{8}$ Hasil penelitian $\quad$ Suryadi $^{9}$, yang menggambarkan bahwa ada hubungan yang signifikan antara hamil terhadap 9 unsur pelayanan yaitu prosedur pelayanan, kedisiplinan petugas pelayanan, tanggung jawab petugas pelayanan, kemampuan petugas pelayanan, kecepatan pelayanan, keadilan mendapat pelayanan, kesopanan dan keramahan petugas pelayanan, kenyamanan lingkungan dan keamanan pelayanan yang diteliti yang rata-rata berada pada kategori mutu dengan persepsi kepuasan ibu hamil dalam pelayanan ANC.

\section{Hubungan Umur Dengan}

\section{Kepuasan Pelayanan ANC}

Berdasarkan hasil penelitian diketahui bahwa kepuasan ibu hamil berdasarkan kategori umur adalah pada responden umur muda yang kurang puas sebanyak 18 orang $(64,3 \%)$ dan yang puas sebanyak 13 orang $(36,1 \%)$, sedangkan umur tua yang kurang puas sebanyak 10 orang $(35,7 \%)$ dan yang puas sebanyak 23 orang $(63,9 \%)$.

Dari hasil uji statistik di ketahui $\chi^{2}$ hitung lebih besar dari $\chi^{2}$ tabel maka disimpulkan H0 ditolak berarti ada hubungan antara umur dengan kepuasan pelayanan ANC. 
Hal ini berarti semakin tua umur semakin banyak pengalaman yang telah didapatkan salah satunya pengalaman terhadap pelayanan ANC sehingga cenderung lebih mudah menerima dan merasa puas dengan pelayanan yang diberikan, begitupun sebaliknya, kemungkinan orang yang berumur muda cenderung kurang merasa puas karena belum banyaknya pengalaman yang di dapat sehingga pelayanan yang diberikan akan merasa kurang.

Secara teoritis, bahwa semakin tua usia memiliki harapan yang lebih rendah dan cenderung lebih mudah puas dari pada usia yag relativ muda. ${ }^{10}$

Hasil ini sesuai dengan penelitian Putri ${ }^{11}$ dilaksanakan RB Srilumintu Surakarta menunjukkan ada hubungan antara kepuasan ANC dengan usia ibu hamil.

\section{Hubungan Pendidikan Dengan Kepuasan Pelayanan ANC}

Berdasarkan hasil penelitian diketahui bahwa kepuasan ibu hamil berdasarkan kategori pendidikan adalah pendidikan tinggi yang kurang puas sebanyak 18 orang
$(64,3 \%)$ dan yang puas sebanyak 12 orang (33,3\%), sedangkan pendidikan rendah yang kurang puas sebanyak 10 orang $(35,7 \%)$ dan yang puas sebanyak 24 orang $(66,7 \%)$.

Dari hasil uji statistik diketahui $\chi^{2}$ hitung lebih besar dari $\chi^{2}$ tabel maka kesimpulan $\mathrm{H}_{0}$ ditolak berarti ada hubungan antara pendidikan dengan kepuasan ANC. Hasil ini berarti orang berpendidikan tinggi yang mempunyai status ekonomi, status sosial tinggi serta pengetahuan yang tinggi mempunyai ekspektasi tinggi terhadap pelayanan yang diberikan oleh bidan desa sehingga apabila pelayanan yang diberikan tidak sesuai dengan harapannya maka akan dikatakan tidak puas. Begitu pun sebaliknya ibu hamil yang berpendidikan rendah cenderung memiliki tingkat rasional yang rendah sehingga cepat merasa puas karena pendidikan yang rendah berpengaruh terhadap penilaian kepuasan.

Hasil ini diperkuat oleh Siagian $^{12}$, semakin tinggi tingkat pendidikan seseorang semakin besar pula keinginan dan harapannya. Hasil penelitian Anwar (2004) 
menyatakan bahwa tingkat

pendidikan berhubungan dengan

kepuasan ibu hamil artinya semakin tinggi tingkat pendidikan seseorang maka akan semakin tinggi kebutuhan dan tuntutan pada penyedia pelayanan.

\section{Hubungan pekerjaan dengan kepuasan pelayanan ANC}

Berdasarkan penelitian diketahui bahwa kepuasan ibu hamil berdasarkan kategori pekerjaan adalah bekerja yang kurang puas sebanyak 17 orang $(60,7 \%)$ dan yang puas sebanyak 11 orang $(30,6 \%)$ sedangkan tidak bekerja yang kurang puas sebanyak 11 orang $(39,3 \%)$ dan yang puas sebanyak 25 orang $(69,4 \%)$.

Dari hasil uji statistik diketahui $\chi^{2}$ hitung lebih besar dari $\chi^{2}$ tabel maka kesimpulan $\mathrm{H}_{0}$ ditolak berarti ada hubungan antara pekerjaan dengan kepuasan ANC. Hasil ini menunjukkan bahwa ibu hamil yang bekerja cenderung sering bersosialisasi dengan masyarakat lainnya sehingga informasi, pengalaman dan pengetahuan secara tidak langsung akan bertambah hal ini akan berpengaruh terhadap 


\section{KESIMPULAN DAN SARAN}

Berdasarkan hasil penelitian dari beberapa faktor yang berhubungan dengan kepuasan pelayanan ANC di Bidan Desa Kungkai Tahun 2017 maka dapat diambil kesimpulan sebagai berikut: 1). Distribusi nilai IKM pelayanan antenatal di Bidan Desa Kungkai tahun 2017 sebesar 56,6 dengan mutu pelayanan $\mathrm{C}$ dan kinerja pelayanan kurang puas; 2).Ada hubungan yang bermakna antara umur ibu hamil, pendidikan ibu hamil, dan status pekerjaan ibu hamil terhadap pelayanan antenatal di Bidan Desa Kungkai tahun 2017.

Dari penelitian ini saran yang dapat diberikan adalah 1). supaya dilakukan penyuluhan dan monitoring peningkatan mutu pelayanan ANC yang di selenggarakan oleh Bidan Desa Kungkai yang difasilitasi oleh Puskesmas Bangko; 2). Memberikan perhatian prioritas pada ibu hamil usia muda, berpendidikan tinggi dan ibu hamil yang bekerja serta melakukan peningkatan mutu pelayanan pada aspek-aspek kepuasan

\section{KEPUSTAKAAN}

1.Kemenkes RI dan BKKBN. Survei Demografi Kesehatan Indonesia. Jakarta; 2012.

2. Salmah \& Rusmiati. Asuhan Kebidanan Antenatal. Jakarta. EGC; 2006.

3. Dinas Kesehatan Propinsi Jambi. Buku Profil Kesehatan Provinsi Jambi 2014. Jambi; 2014.

4. Saifudin, AB. Buku Acuan Nasional Pelayanan Kesehatan Maternal dan Neonatus. Jakarta: Bina Pustaka Prawirohardjo; 2014.

5. United Nations. Millenium Development Goals 2013. New York: UN; 2013.

6. Departemen Kesehatan RI. Profil Kesehatan Indonesia Tahun 2014. Jakarta: Kemenkes; 2014.

7.PohanI.Jaminan mutu layanan kesehatan. Jakarta: EGC; 2007.

8. Hafizurrachman. Pengukuran Kepuasan Suatu Institusi Kesehatan. Majalah Kedokteran Indonesia.2004; 54(7).

9. Suryadi. Analisis Pengaruh Persepsi Mutu Layanan Antenatal Care (ANC) Terhadap Kepuasan Ibu Hamil di Pskesmas Lamepayung Kabupaten Kuningan Propinsi Jawa Barat, Unipersitas Diponegoro, Semarang; 2009.

10. LoudonDLandDella BittaA. Consumer Behaviour: Concepts and Applications; 1988.

11. Putri EC (2012) Faktor-faktor Kepuas an Ibu Hamil padaPelayanan Antenatal CareDan Post Persalinan Di RB Srilumintu Surakarta. Tesis. Surakarta: UMS; 2012. 